\title{
ИСТОРИЈА, ОБРАЗОВАНИЕ, КАРТИ, СТАТИСТИКА, ПРОПАГАНДА - ГРЦИЈА И ОСМАНЛИСКА МАКЕДОНИЈА ВО ХІХ ВЕК
}

\section{Кратка содржина}

Појавата на Големата идеја, која е поврзана со говорот на Јоанис Колетис во Грчкото собрание во јануари 1844 година, предизвикала голема промена во однос на грчките територијални аспирачии кон Османлиската Империја, која била единствениот сосед на Гриија сѐ до 1912 година. Македонија, која била дел од османлиската држава, станала чел на грчките територијални аспирачии. Појавата на Големата идеја довела и до промена во толкувањето на минатото од страна на грчките интелектуалџи. Па така, античка Македонија, која била сметана за окупаторска сила на стара Гриија, наеднаи станала дел од грчкото минато. Слично се случило и со Византија. Во Гриија започнал еден период во кој се печателе статистики и карти со една чел - да се покаже дека во Македонија преовладувало грчкото население. Меѓутоа, тоа било далеку од вистината. 3атоа воопшто не било изненадување формирањето на Атинското здружение за ширење на грчката писменост. Исто така, не било изненадување ниту, пак, финансирањето на неговата активност од страна на грчката држава. Секако, најголемиот дел од средствата биле одвојувани за Македонија.

Клучни зборови: МАКЕДОНИЈА, ГРЦИЈА, КАРТИ, САТИСТИКА, ПРОПАГАНДА

Евангелос Кофос во една своја статија забележал дека Крит, Епир и Тесалија имале приоритет во однос Македонија. Тој, исто така, смета дека помеѓу Грците во Атина, во средината на XIX век, имало слабо знаење за основните факти за состојбите во Македонија и на Балканот. ${ }^{1}$ Грците не биле ниту сигурни за карактерот на територијата на Македонија. Според некои гласишта, Теодорос Делијанис прашал некој трговец од Серес за трговскиот обем на пристаништето на градот. Ова прашање било навредливо за трговецот кој кога се вратил во Серес раскажувал за незнаењето на грчкиот политичар. ${ }^{2}$ Трговецот сигурно бил шокиран

\footnotetext{
${ }^{1}$ E. Kofos, Dilemmas and orientations of Greek policy in Macedonia 1878-1896, Balkan Studies, 21, Institute for Balkan studies, Thessaloniki, 1980, p. 45

${ }^{2}$ G. Michalopoulos, Greece and Macedonia: 1878-1910. Political parties, irredentism and the Foreign Ministry, PhD thesis, University of Oxford, 2013, p. 8-9
} 
како Делијанис не знаел дека Серес нема пристаниште бидејќи градот не бил на море. Меѓутоа, како што забележал Георгиос Михалопулос, грчките политичари, иако можеби не знаеле географија, биле свесни дека Македонија била помеѓу приоритетите на Грција. ${ }^{3}$

Зборовите на Кофос не се без основа. Во Грција, освен слабото познавање на состојбите во османлиска Македонија, се водела и една интересна дебата помеѓy грчките интелектуалци. Имено, денес тоа звучи изненадувачки, во Грција се расправало дали античките Македонци биле дел од античката грчка култура, традиција и историја, поточно дали биле Грци. ${ }^{4}$ Слично се случувало и кога била во прашање историјата на Византија, која денес, во Грција, се смета за составен дел од грчката историја, цивилизација, традиција и култура.

Говорот на Колетис во Грчкото собрание во јануари 1844 година и појавата на Големата идеја имале свое влијание и врз начинот на кој се гледало на минатото. Желбата за територијално проширување на грчката држава постепено и неизбежно довела до реинтерпретација на грчката историја. ${ }^{5}$ Така, постепено античките Македонци, нивната држава и историја започнале да се сметаат како дел од грчкото минато и традиција. Историјата станала значаен извор за докажување на правото врз одредена територија, во овој случај на грчкото историско право врз Македонија. Константинос Папаригопулос, основоположник на современата грчка историографија, одиграл огромна улога во внесувањето на античка Македонија како дел од грчката историја и наследство. ${ }^{6}$ Папаригопулос, во 1853 г., во еден гимназиски учебник напишал дека кралот на Македонија, Филип, кој во 338 г. пр.н.е. ја наметнал својата власт над цела Грција, не бил странец. Македонците, иако така не биле споменати во пораните фази, всушност, биле Грци. ${ }^{7}$ Спиридон Замбелиос, голем интелектуалец, по потекло од јонските острови, во едно свое дело забележал дека не било мудро што античките Македонци биле сметани како окупатори и странци во Грција. ${ }^{8}$ Всушност, преоценувањето на улогата на античките Македонци било поврзано со обезбедување на идејата за грчко единство. Во оваа насока е неизбежно да го споменеме говорот на Константинос Асопиос. Тој, во својот говор по повод стапувањето на ректорската позиција на Атинскиот универзитет во 1856 година, нагласил дека Александар Велики бил симбол на единството. ${ }^{9}$

${ }^{3}$ Исто, с. 10

${ }^{4}$ За дебатите во Грција околу античка Македонија, по создавањето на грчката држава, види: D. Jovanovski, Science and Politics-The Creation and Promotion of the Northern Line of the Greek Aspirations in Ottoman Macedonia, The Name Issue, MIC, Skopje, 2013, p. 371-387

${ }^{5}$ A. Smith, The cultural foundations of nations: hierarchy, covenant and republic. Blacwell Publishing, 2008, p. 163

${ }^{6}$ Види повеќе кај: Д. Јовановски, Константинос Папаригопулос и Македонија; Историја, историографија и настава по историја, СИРМ, Скопје, 2007, с. 187-195

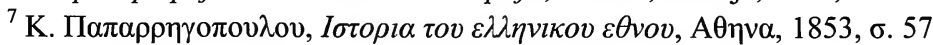

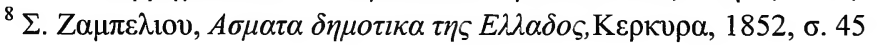

${ }^{9}$ K. N. Demetriou, Historians on Macedonian imperialism and Alexander the Great, Journal of Modern Greek Studies, v. 19, 2001, p. 54, f.13 
Кога се говори за историското право врз одредени територии, не треба да се заборави и Византија и нејзината историја. Во првата фаза од развојот на Грциja, и византиското минато, слично како и она на античка Македонија, не било сметано за грчко. Во очите на влијателните грчки интелектуалци, задоени со просветителските идеи, Византија била олицетворение на заостанатост. Меѓутоа, и тоа се променило. Потребата од историјата за националните цели налагала и рехабилитација на Византија. Папаригопулос, историчарот кој најмногу придонел за инкорпорирањето на античка Македонија во рамките на грчката историја, а со тоа и во рамките на современиот грчки идентитет бил заслужен и за рехабилитацијата на Византија. Историјата на Византија претставувала значаен дел од повеќетомната Историја на грчкиот народ напишана од Папаригопулос. Речиси три од петте тома на второто издание на оваа дело, завршени во периодот 1885-1887 година, биле посветени на Византија. ${ }^{10}$ Неговата рехабилитација на Византија и нејзиното вметнување во грчкиот континуитет од антиката до современоста имала големо, ако не и решавачко, влијание врз грчката политичка мисла. ${ }^{11}$ Како што забележал Китромилидис, Византија станала значаен дел од Мегали идејата, особено со времето на Македонската и Комненската династија. ${ }^{12}$ Иако некои нема да се сложат, сепак, рехабилитацијата на Византија била потребна кога е во прашање Македонија. Многу брзо приказната за Василиј Бугароубиецот добила забележителен простор во грчкото општество. Така со победата на Василиј II над војските на Самуил се сакало да се покаже дека во Македонија се води битка со истиот противник - Бугарите, која повторно требала да биде добиена. ${ }^{13}$ Во периодот што следувал Византија и Василиј биле повеќе од потребни за грчката кауза во Македонија.

Вметнувањето на античка Македонија и на Византија во грчката историја, традиција, култура и идентитет имало свој одраз и во образованието. Во периодот од 1834 до 1882 година може да се забележи дека античката историја доминирала кога била во прашање историјата како дел од образованието. Во споменатиот период биле издадени 59 учебници кои ја обработувале античката грчка историја. ${ }^{14}$ Во поглед на застапеноста на Византија во споменатиот временски период, има една интересна појава. Иако Византија постепено била рехабилитирана, во грчкиот образовен систем нејзината застапеност не била голема. За историјата на Византија и освојувањето на Цариград од страна на османлиите биле објавени вкупно 9 учебници. ${ }^{15}$ Позицијата на Византија во предметот историја во грчкиот обра-

${ }^{10} \mathrm{P}$. Kitromilides, On the intellectual content of Greek nationalism: Paparrigopoulos, Byzantium and the Great idea in: D. Ricks and P. Magdalino (ed.) Byzantium and the Modern Greek identity, Ashgate Publishing, 1998, p. 28

${ }^{11}$ Исто, с. 31

12 Исто

13 За ова прашање види кај: P. Stephenson, The legend of Basil the Bulgar Slayer, Cambridge University Press, 2003, p. 113-134

14 T. G. Zervas., „Resurrecting the Past, Constructing the Future: A Historical Investigation on the Formation of a Greek National Identity in Schools, 1834-1913“(2010) Dissertations Paper 156, Loyola University Chicago, p. 162

${ }^{15}$ Исто, с. 163 
зовен систем се засилила по 1882 година. Тогаш во рамките на министерството за образование бил формиран еден комитет кој требал да го одобрува издавањето на учебниците. Според општата согласност која постоела меѓу оние што се занимавале со наука и се грижеле за историјата како наставен предмет, грчката историја требало да биде поделена според периодизацијата која ја направил Папаригопулос, односно на античка, византиска и современа. ${ }^{16}$ Кога е во прашање образованието во Грција, сметаме дека е добро да се напомене дека тоа било во корелација со националните аспирации. Грчката држава давала стипендии студентите да посетуваат обука во училишта кои биле создадени во европските делови на османлиската држава. ${ }^{17}$ Оваа појава била поврзана, на некој начин, и со Атинскиот универзитет. Тука студирале извесен број студенти кои потекнувале од османлиската држава. Грција сакала, по нивното дипломирање, да ги искористи нивните услуги за сопствените аспирации. Споменувајќ ги грчките територијални аспирации или националното прашање, не треба да се заборави и основното и средното образование. Така на часовите по географија биле користени карти на кои териториите помеѓу Дунав и Егејско Море не биле означени со терминот Балкан, туку како „Хеленски Полуостров“. ${ }^{18}$ На картите сите територии кон кои Грците имале аспирации и ги сметале за неослободени биле означени како грчки. ${ }^{19}$ Овие карти биле набавувани од Силогосот за ширење на грчката писменост. Очекуваните резултати биле задоволителни за тие што го контролирале образовниот процес во Грција. Терминот Хеленски Полуостров не се употребувал само на картите, туку и во учебниците по географија и историја. ${ }^{20}$ Тука би сакал да дадам еден пример од учебник по географија на Јоанис Асимакопулос. Авторот во делот под наслов „Хеленски Полуостров“, за потребите на учениците, напишал дека малите држави на полуостровот биле големи меѓусебни ривали, гледајќ дека османлиската држава се распаѓa тие се карале за нејзиното наследство. Според напишаното од авторот, Грција требало да го добие најголемиот дел од териториите на османлиската држава. Учебникот на Асимакопулос не бил исклучок. Во еден друг учебник по географија, напишан од познатиот универзитетски професор Мицопулос, било напишано дека цела Македонија како татковина на Александар Велики била единствено грчка со извесен број Турци и Бугари. ${ }^{21}$ Влијанието на Мегали идејата и барањето на територии кои не биле во составот на грчката држава може да го видиме и во еден учебник по историја од 1891 година, напишан од С. Циванопулос, кој

\footnotetext{
${ }^{16}$ Исто, с. $177-178$

${ }^{17}$ I. Betsas, The objectives of the Greek foreign ministry for Greek education within the Ottoman state (1871-1912): The setting of objectives and the fundamental axes of activity in: Nikos Terzis (ed.), Education in the Balkans: From the Enlightenment to the Founding of the Nation states, Kyriakidis Brothers, Thessaloniki, 2000, p. 247

${ }^{18}$ W. Miller, Greek life in town \& country, George Newnes ltd. ,London, 1905, p.140

${ }^{19}$ Исто

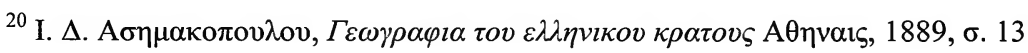

${ }^{21}$ R. Sh. Peckham, National Histories, national state. Nationalism and the politics of place in Greece, I.B. Tauris publishers, London - New York, 2001, p. 144
} 
се однесувал на новата грчка историја. Според авторот на овој учебник, грчката држава била некомплетна без нејзините територии од минатото на населението кое таму живеело. ${ }^{22}$ Географијата и историјата, забележала Деметра Цанаки, станале поетски простори низ кои интелектуалците сакале да ја мобилизираат целата нација за прашањето на политичкото обединување. ${ }^{23}$

Споменатиот говор на Колетис ја отворил вратата за подруги размислувања за прашањето до каде требало да се протега Грција. Професорот на Правниот факултет на Атинскиот универзитет Николаос Сариполос, во еден разговор со грчкиот крал Георгиос I, во неослободена Грција ги вклучил Крит, Тесалија, Епир, Тракија, Македонија, Црно Море до Трабзон, Мала Азија, егејските острови и Кипар. ${ }^{24}$ Интелектуалците и политичарите не биле единствени кои биле опчинети со Мегали идејата и со желбите за грчко територијално проширување. Македонија била многу посакувана област. Во оваа насока, сметаме дека е добро да покажеме како и грчката кралица Амалија ја преферирала Македонија. Таа на еден бал во Атина била запрашана која област повеќе ја посакувала - Тесалија или Македонија? Одговорот на кралицата бил експресен - Македонија. ${ }^{25}$ Одговорот на кралицата е најдобро објаснување до каде стигнал грчкиот иредентизам. Едноставно голем дел од општествените фактори биле опфатени од него.

Грчките територијални аспирации и иредентизмот не биле присутни само во образованието или во весниците. Грците настојувале своите аспирации да ги прикажат и надвор од границите на својата држава. Така, на пример, тие издале неколку карти во последните три децении на XIX век во кои најдобро можат да се видат нивните територијални аспирации кон Османлиската Империја и во кои била опфатена Македонија. Во оваа насока може да ни послужи и книшката со карта која се однесувала на народносниот состав на Балканот, издадена во Лондон во 1877 г. од страна на издавачката куќа Стенфорд. ${ }^{26}$ Основа на оваа мала книшка биле податоците добиени од Атинскиот силогос за ширење на грчката писменост. Затоа воопшто не било чудно што во објаснувањата придружени кон картата се тврдело дека населението во црноморските градови, Македонија и Тракија имало грчко потекло, јазик, традиција и вера. ${ }^{27}$ Поточно, во однос на населението во северна Македонија и Тракија, како што било напишано во книшката, „мешаното

${ }^{22}$ T. G. Zervas., „Resurrecting the Past, Constructing the Future: A Historical Investigation on the Formation of a Greek National Identity in Schools, 1834-1913 “, p. 187

${ }^{23}$ D. Tzanaki, Women and Nationalism in the Making of Modern Greece, Palgrave Macmillan, 2009, p. 114-115

${ }^{24}$ V. Roudometof, Invented traditions, symbolic boundaries and national identity in Southeastern Europe: Greece and Serbia in comparative historical perspective (1830-1880), East European Quarterly, XXXII, n.4, January, 1999, p. 463, f.55

${ }^{25}$ H. Rumbold, Recollections of a diplomatist, Edward Arnold, London, 1902, p. 119

${ }^{26}$ Х. Р. Вилкинсон, Картите и политиката. Преглед на етнографската картографија на Македонија, Македонска книга, Скопје, 1992, с.

${ }^{27}$ Н. Данова, Националният въпрос в гръцките политически програми през XIX век, Наука и изкуство, София, 1980, с. 228 
грчко и бугарско население во овие региони постепено било соединето во едно ново и заедничко тело, кое не било ниту чисто бугарско ниту чисто грчко, туку припаѓало на двете раси. Ова мешано население може најсоодветно да се означи како 'бугарофони Грци““. ${ }^{28}$ Кога веќе ја споменавме оваа книга, интересно е да се напомене еден став на турската историчарка Ипек Јосмаоглу. Според неа, оваа книшка со картата која сите ја нарекуваат картата на Едвард Стенфорд, всушност, е дело на грчкиот дипломатски претставник во Лондон Јоанис Генадиос. ${ }^{29}$ Ова тврдење на Јосмаоглу е прифатливо и логично ако се има предвид фактот дека Едвард Стенфорд бил издавач на карти и атласи. Во крајна линија, брзиот превод на оваа карта и на грчки јазик од страна на Лазаридис во 1877 година во Атина ${ }^{30} \mathrm{e}$ добра потврда на ставот на турската историчарка. Непосредно пред почетокот на Берлинскиот конгрес била издадена брошура со една карта во прилог. Насловот на оваа брошура е „Објаснувачка забелешка за етнографската карта на грчките, словенските, албанските и романските земји направена од Хенри Киперт“. ${ }^{31}$ Споменатата историчарка Јосмаоглу забележува дека текстот во неа бил напишан од Папаригопулос со согласност на Киперт. ${ }^{32}$ Оваа брошура била издадена по неколкумесечна преписка и дискусија помеѓу Папаригопулос и Киперт. Причина за дискусијата била картата на германскиот картограф од 1876 година, каде што за мнозински грчки делови од османлиска Македонија биле означени само најјужните крајбрежни области на споменатиот регион. Тоа било причина за аларм во Атина и затоа започнала комуникацијата помеѓу двајцата научници, која завршила позитивно за грчките интереси. Како и да е, грчкиот историчар успеал да го убеди Киперт и во нешто многу поважно од текстот. Имено, како грчки ги означил областите во Македонија кои се протегале јужно од линијата Охрид - Битола, Струмица - Неврокоп. Грчкиот интелектуалец и новинар Клеантис Николаидес направил чекор понатаму. Како што забележуваат Гунарис и Михаилидис, оваа негова книга била првата грчка студија за Македонија објавена на некој европски јазик. ${ }^{33}$ Логично се поставува прашањето - каде биле прикажани на карта грчките аспирации во Македонија во оваа книга? Одговорот е многу едноставен на самиот почеток. ${ }^{34}$ Николаидес дал една етнографска и лингвистичка карта на Македонија, која

${ }^{28}$ I. Yosmaoğlu-Turner, The priest's robe and the rebel's rifle: Communal conflict and construction of national identity in Ottoman Macedonia 1878-1908, PhD dissertation, Princeton University, November, 2005 , p. 84

${ }^{29}$ Исто, с. $83-84$

${ }^{30}$ Н. Данова, Националният, c, 228

${ }^{31}$ Notice explicative sur la Carte Ethnographique des pays Helleniques, Slaves, Albanais et Roumains, dessinee par M. Henri Kipert, Kerkes \& Hohmann. Berlin, 1878

${ }^{32}$ Ipek Yosmaoğlu-Turner, The priest's robe and the rebel's rifle, p. 94

${ }^{33}$ В. Гунарис, Ј. Михаилидис, Перото и мечот: преглед на историографијата за македонското прашање, во: Виктор Рудометов, Македонското прашање, Евро Балкан пресс, Скопје, 2003 , c. 143

${ }^{34}$ C. Nicolaides, La Macedoine, la questioin macedonienne dans l'antique, au moyen-age et dans la politique actuelle, Johannes Ræde, Berlin, 1899 
како што самиот нагласил ја базира на картата на Киперт од 1878 г. Во неа како територии на кои преовладува грчкиот јазик и грчкото население се прикажани македонските области под линијата Битола - Демир Капија -Струмица - Мелник - Неврокоп. Оваа негова карта подоцна станала една од главните аргументи кои ги користеле грчките политичари во насока на остварување на своите интереси. Исто така, не треба да се заборави дека таа е користена од страна на разни научници кои се занимавале со Македонија, како што е, на пример, познатиот англиски географ Вилкинсон, кој забележал: „Аспирацијата на Грција кон Македонија стана сосема јасна со книгата за Македонија на Николаидес... “35 Европа добила карта на Македонија која одговарала на грчките интереси и аспирации.

Листајќ по книгите, брошурите и статиите напишани од грчките интелектуалци во XIX век, се заинтересирав и за статистиките кои тие ги правеле за османлиската држава, особено за Македонија. Првата статистика која ја сретнав потекнува од средината на XIX век, поточно од 1853 година. Авторот на оваа статистика, Сариполос, врз база на, како што напишал, своите истражувања стигнал до следните бројки - вкупниот број жители во Македонија изнесувал 760.000 од кои 500.000 биле Грци, 120.000 биле Власи и Словени, 100.000 Турци и 40.000 Евреи. $^{36}$ Тука треба да напоменам дека Сариполос не дава подетални податоци за распоредот на населението по региони во Македонија. Како и да е, може да забележиме во оваа статистика на Сариполос дека вкупниот број Словени, Турци, Власи и Евреи во Македонија е речиси за два пати помал од оној на Грците. Така, може да претпоставиме дека целта на Сариполос со овие статистички бројки била повеќе од јасна - грчкиот елемент доминирал во османлиска Македонија, а така ќе биде и во иднина. Оваа статистика била направена од приватно лице. Логично се поставува прашањето дали постои некоја статистика која била составена од страна на службеници на грчката држава. Одговорот е позитивен, иако таа статистика се однесувала само за еден дел од територијата на Македонија. На 14 август 1880 година грчката влада поднела меморандум до амбасадорите на големите сили, кој бил наменет, всушност, за европската комисија задолжена за организација на Источна Румелија. ${ }^{37}$ Во меморандумот грчката влада бара во Македонија да не се наруши принципот на рамнотежа на народностите, бидејќи тоа било важно за рамнотежата на Медитеранот. Македонија, според авторите на меморандумот, била клуч на Егејското Море и спојна врска помеѓу Епир и Тесалија, од една страна, и Тракија, од друга страна, и затоа Македонија била посебно важна и барала најсериозно внимание од комисијата за реформи. Рамнотежата од која, според грчкиот меморандум, зависел успехот на реформите не можела да се постигне без едно разграничување во Македонија, кое можело, пак, да стави крај на активностите на странските агенти. Демаркационата линија би започнала од Родопите, па би минувала помеѓу Струмица и Радовиш од каде што би продолжила кон вливот на Црна

\footnotetext{
${ }^{35}$ Х. Р., Вилкинсон, Картите и политиката., с. 138

${ }^{36}$ N. Saripolos, Pro Graecia, t. 2, Athenes, 1853, p. 12

37 Д. Јовановски, Грчката балканска политика и Македонија 1830-1881, Бато и Дивајн, Скопје, 2005, с. 197
} 
Река во Вардар, при што би го опфатила Тиквеш и би продолжила кон Битола, оставајќк ги од десно околината на Прилеп и Охрид и опфаќајќи ја целата област на Корча и оттука да се спои со новата грчка граница преку Колоња, Анаселица и Гревена. Југоисточниот дел би ги опфатил: 1) целиот солунски вилает освен казата Велес; 2) нахијата Мариово и казите Битола, Лерин, Корча, Колоња, Анаселица, Кајлари, Кожани и Серфиџе од Битолскиот вилает; 3) околината на Гревена, која била во состав на Јанинскиот вилает. Овој меморандум не би бил интересен за нашата тема доколку во него не биле дадени и статистички податоци за османлиска Македонија. Нормално, податоците се однесуваат само за југоисточниот вилает. Во него живееле, според дадените бројки во меморандумот, 380.000 чисти Грци; 75.000 Гркоалбанци, Грковласи и Албанци; 425.000 Бугари и Бугарофони; 450.000 муслимани и 63.000 Евреи и други или вкупно 1.397 .000 жители. Забележливо е во овој меморандум дека бројот на Грците не е доминантен во однос на другите етнички групи. Кога е во прашање оваа статистика на грчката влада, може да кажеме дека таа претставувала прва од таков вид која била претставена пред претставниците на големите сили. Така европската дипломатија официјално добила една статистика која целосно ги изразувала грчките погледи за составот на населението во османлиска Македонија. Европската јавност го немала тоа задоволство, но и тоа ќе се случи до крајот на векот. Оваа статистика била направена од страна на новинарот Николаидис, кој, како што видовме погоре, составил и една карта за грчките аспирации кон османлиска Македонија. Во Косовскиот вилает, поточно Скопскиот санџак, покрај македонските кази, додадена е и казата Качаник. Според Николаидес, во овој санџак имало 276.008 жители од кои Грци 5.036; Муслимани - 117.781; Бугари - 137.134; Срби - 9.831; Католици - 398, Евреи - 1.570 и Роми $4.208 .^{38}$ За Битолскиот вилает, Николаидис ни го дава составот на населението за двата санџака кои биле во османлиска Македонија - Битолскиот и Серфиџе - Кожани. Па така во Битолскиот санџак имало вкупно 324.629 жители од кои Грци (православни) - 169.030, Бугари (шизматици) - 87.159, Муслимани (Албанци, Турци) и Евреи - 5.000. ${ }^{39}$ Николаидис, како и Ватикиотис во 1884 година и Калостипис во 1885 година во Македонија го става и санџакот Корча. Пишувајќи за прашањето на додавањата на некои области кон Македонија и одземањето на други од неа, Лазар Мојсов забележал дека тоа било намерно правено од грчка страна со намера бројот на грчкото население да се покаже како релативно мнозинство во Македонија со јасна цел да се покаже дека Македонија е грчка. ${ }^{40}$ Санџакот Серфиџе - Кожани имал 100.181 жител, од кои Грци - 71.230; Турци 27.475 , Власи - 1.275; Роми - 180 и Евреи $-21 .{ }^{41}$ Кога е во прашање Солунскиот вилает, Николаидис, како и во случајот со Битолскиот вилает, дава податоци спо-

${ }^{38}$ C. Nicolaides, La Macedoine, la questioin macedonienne dans l'antique, au moyen-age et dans la politique actuelle, p. 25

${ }^{39}$ Исто, с. 26

40 Л. Мојсов, Македониите во Егејска Македонија, Мисла, Скопје, 1989, с. 145

${ }^{41} \mathrm{C}$. Nicolaides, La Macedoine, la questioin macedonienne dans l'antique, au moyen-age et dans la politique actuelle, p. 26 
ред кои преовладува грчкиот елемент во сите санџаци на вилаетот. Така, во Солунскиот санџак живееле вкупно 605.769 жители, од кои 232.621 биле Грци; Бугари - 91.708; Власи - 17.494; Турци - 180.735; Роми - 1.670 и Евреи - 73.455. Во Серскиот санџак имало 365.395 жители, од кои, изненадувачки, најмногубројни биле Турците, чија бројка достигнувала 127.810 , а Грците биле на второ место со 124.247 , додека Бугарите достигнале до 108.143 жители. Николаидис ги ставил останатите 5.195 жители во графата - разни. Според него, и во Драмскиот санџак Турците ја сочинувале најголемата заедница. Имено, од 153.400 жители, 103.250 биле Турци, 45.220 Грци, 3.450 Бугари; 1.680 Евреи и 200 останати. ${ }^{42}$ Кога ќе ги собереме сите овие податоци, Македонија, според грчкиот интелектуалец, имала 1.825 .082 жители, од кои $1 / 3$ биле Грци, значи најмногубројната етничка група, согласно со целта на оваа статистика. Овие три статистики се добар пример колку бројките станале важни за докажување на правото врз одредена територија.

Завршувањето на Големата источна криза и инкорпорирањето на Тесалија и на епирскиот град Арта во рамките на грчката држава претставувало нов момент во поглед на грчките аспирации кон Македонија. Оваа османлиска област, за разлика од порано, станала еден од врвните приоритети на грчката надворешна политика и пропаганда. Потребата од нови и плодни територии, заради животниот простор, наметнала агресивна политика кон Македонија. Оваа област во очите на Грците, поради нивното толкување на античкото минато, веќе била гледана како историски грчка земја. Меѓутоа, а тоа е многу интересно за нашава тема, првата книга во Грција, која се однесувала исклучиво за Македонија, била објавена во 1880 година. Автор на оваа книга, која била објавена со наслов „Работата на елинизмот во Македонија“, бил пратеникот во Грчкото собрание, Атанасиос Папалукас Ефтаксиос. ${ }^{43}$ Во оваа книга грчкиот политичар и интелектуалец објаснувал сѐ што треба да се прави во Македонија со цел да се заштитат интересите на елинизмот, кој бил загрозен од дејствувањето на Бугарите. Одговорот на прашањето зошто било потребно објавување книги кои се однесувале на состојбите во Македонија, ако оваа област била грчка територија уште од антиката, може да го најдеме во книгата на Јоанис Калостипис, која била посветена на Македонија. ${ }^{44}$ Калостипис во неговата книга нагласил дека Македонија била срцето на елинизмот, а без неа не можела да постои ниту мала ниту, пак, голема грчка држава. Тој нагласил дека оваа област била основа на грчката големина и обединетост, како и гаранција за грчкото постоење. ${ }^{45}$ Слични размислувања како оние на Калостипис можеме да најдеме и во тогашниот грчки печат. Тука ќе наведам еден пример. Во атинскиот весник „Акрополис“, на 13 август 1889 година, била објавена една статија посветена на Македонија во која било нагласено: „Македонија. Таму е нашата иднина,

\footnotetext{
${ }^{42}$ Исто, с. 27

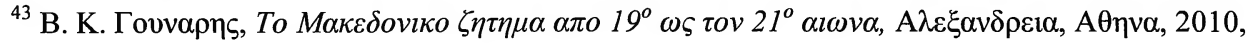
$\sigma .33$

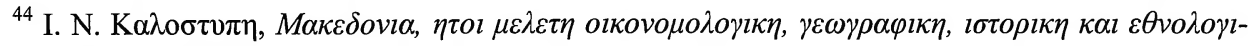
$\kappa \eta, \mathrm{A} \theta \eta v \alpha 1 \zeta, 1886$

${ }^{45}$ Исто, с. 8
} 
нашиот напредок, нашиот живот, нашата големина““. ${ }^{46}$ Овие два примера ни покажуваат зошто Македонија била толку многу важна за Грците и зошто била толку многу посакувана од нивна страна. Интересен за оваа тема е и грчкиот интелектуалец, универзитетски професор и еден од ректорите на Атинскиот универзитет, Неоклис Казазис. Тој бил еден од основачите на здружението „Елинизмос“ и негов долгогодишен претседател. Казасис, како професор, напишал многу книги поврзани со правната наука. Меѓутоа, тој пишувал и на теми поврзани со грчките национални аспирации. Така, во една книга која се однесувала на прашањето што е Грција, а била посветена на грчката младина, Казазис дава интересни толкувања. Во неа го поставил прашањето кои земји ја сочинуваат Грција? Одговорот бил Пелопонез, Централна Грција, Тесалија, Епир, Македонија, Тракија итн. ${ }^{47}$ Епир, Македонија и Тракија не биле дел од територијата на тогашната грчка држава, туку на Османлиската Империја. Грчките аспирации кон овие територии не биле тајна, ниту, пак, биле криени. Меѓутоа, зошто и Казазис пишува, говори и дејствува за грчките интереси во Македонија? Одговорот на ова прашање може да го најдеме во една негова книга од крајот на XIX век. Тој обиколил неколку балкански земји. По враќањето во Грција, Казазис објавил една книга посветена на елинизмот на Балканскиот Полуостров. Во неа, нормално и очекувано, имало место за Македонија. Според него, иднината на грцизмот лежела во оваа османлиска област. ${ }^{48}$ Во оваа книга Казазис дал интересно размислување според кое „како центар на елинизмот треба да се смета Македонија““. ${ }^{49}$ Така, врз база на овие примери, може да разбереме зошто Македонија била толку важна за Грците. Иднината на Грција лежела во неа.

Еден од главните проблеми со кој се соочувала грчката политика во османлиска Македонија бил малиот број Грци во споменатата област. Дејствувањето на македонските преродбеници, но и борбата за црковна самостојност дополнително ја комплицирале позицијата на Грците. Вметнувањето на Македонија во грчкиот иредентизам не би имало никаква смисла доколку на теренот работите не одат во правец на грчките аспирации. Во Атина, следејќи ја ситуацијата на османлиските територии во текот на шеесеттите години на XIX век, размислувале како да ги заштитат грчките интереси. Еден од начините бил засилување на пропагандата преку образованието, како едно од најмоќните средства за наметнување на националната свест. Една поголема група влијателни грчки интелектуалци и политичари, како што се Константинос Папаригопулос, Маркос Рениерис, Јоанис Пантазидис, Леон Мелас, Харилаос Трикупис и др., на 3 април 1869 година во Атина го формирале Силогосот за ширење на грчката писменост. ${ }^{50}$ Новото здру-

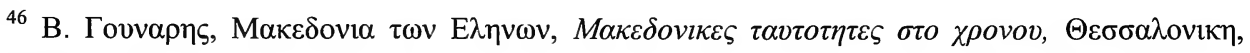
2008, б. 198

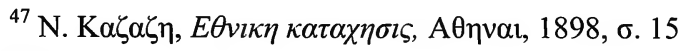

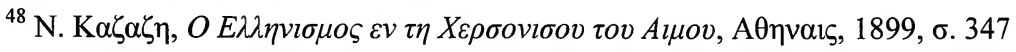

${ }^{49}$ Исто, с. 294

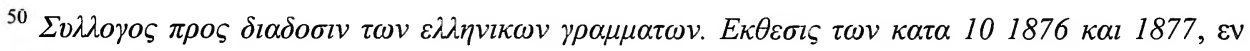
A $\theta \eta v \alpha 15,1878, \sigma .16$ 
жение веднаш добило поддршка од кралот Георгиос I. ${ }^{51}$ Оваа поддршка не била случајна и куртоазна. Во периодот кој следувал активностите на ова здружение биле помагани од страна на грчката држава. Нејзините конзули во османлиската држава биле на располагање на Силогосот. Сепак, тука мора да забележам една работа. Кога се анализира статутот на ова здружение, не може да не се забележи дека неговата основна цел било ширење на грчката пропаганда во османлиската држава, со посебен акцент на Македонија. Но, дејствувањето на претставниците на здружението покажувало дека токму Македонија била цел на ова здружение, но и на грчката пропаганда, воопшто. Во прилог на ова мое тврдење е следниов пример. Елени Белија, врз основа на архивските материјали од Архивот на грчкото министерство за надворешни работи, дава споредбен преглед за пратените средства за поддршка на грчката пропаганда во Македонија, Епир и Тракија преку Комитетот за поддршка на грчката црква и образование. ${ }^{52}$

\begin{tabular}{|l|lr|ll|ll|}
\multicolumn{3}{c}{ Епир } & \multicolumn{2}{c}{ Македонија } & \multicolumn{2}{c|}{ Тракија } \\
\hline $1888 / 89$ & 43.263 дрх. & $9 \%$ & 322.092 дрх. & $71 \%$ & 90.298 дрх. & $20 \%$ \\
\hline $1890 / 91$ & 50.302 & $11 \%$ & 323.935 & $70 \%$ & 86.958 & $19 \%$ \\
\hline $1897 / 98$ & 31.698 & $13 \%$ & 175.381 & $74 \%$ & 32.679 & $13 \%$ \\
\hline
\end{tabular}

Не е потребна анализа за да се забележи дека убедливо најголеми средства биле одделувани за Македонија. Здружението кое го споменува Белија било основано во Атина во 1887 година со цел да ги замени активностите на Силогосот за ширење на грчката просвета. Меѓутоа, тоа било само козметичка промена, суштината останувала иста - да се зголеми бројот на оние што се изјаснувале за Грци во Македонија. Но, да се навратиме на целта на Атинскиот силогос. Грчката наука, воопшто, има став дека Атинскиот силогос имал цел да ги мобилизира османлиските Грци против странската националистичка пропаганда, ${ }^{53}$ но некои настани го покажуваат спротивното. Имено, заштитата на грчките интереси била проткаена со желбата за зголемување на бројот на Грците во османлиска Македонија. Тоа може да го забележиме на Конгресот на грчките силогоси, кој бил одржан во Атина во 1879 година. Тогаш било изјавено: „Усилбите да се распространи грчката култура, грчкото образование и воспитување кај грчките деца и некои други другојазични популации во грчките заедници... како што се Власите и Албанците во Епир и Македонија и оние што говорат бугарски во Македонија и во Тракија... да се направи посакуваната целосна грцизација““. ${ }^{54}$ Всушност, постоењето на Силого-

${ }^{51}$ Исто, с. $16-17$

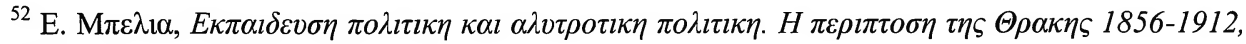

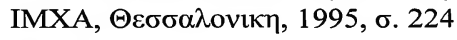

${ }^{53}$ L. Papadakis, Teaching the nation. Greek nationalism and the Education in nineteenth century Macedonia, IBS, Thessaloniki, 2006, p. 18

${ }^{54}$ K. Bonides, S. G. Paskalas, K. S. Balabani, Nationalism and education: The propagation of the Great idea of Greek nationalism through education in the European territories of the Ottoman Empire in the late $19^{\text {th }}$ century in: Education in the Balkans: From the Enlightment to the founding of the nation states. Kyriakidis Brothers, Thessaloniki, 2000, p. 214 
сот, а подоцна и на други здруженија имало логика кога биле во прашање грчките интереси. Друга работа е дали тие биле успешни. Така, грчкиот историчар Василис Гунарис смета дека Грците се покажале неспособни да го усогласат нивното класично ориентирано образование кон попрактичните потреби на македонските селски општества. ${ }^{55}$ Сепак, тоа не значи дека оваа нивна агресивна пропагандна активност немала одредени резултати.

На крајот, може да заклучиме дека во втората половина на XIX век грчката држава презела силни активности кои имале цел да ја претстават Македонија, или, пак, најголемиот дел од неа, како грчка историска територија која требала да влезе во составот на Грција. За таа цел дошло и до промена на толкувањата за античкото минато на Македонија, но и до рехабилитација на Византија. Пропагандата со карти, статистики и дејствување на здруженија за ширење на грчкото образование биле средства за засилување на позициите на Грција во регионот и претставување на Македонија како дел од грчката традиција, историја, култура и фолклор. Потребата од тоа била јасна - Македонија морала да стане грчка. Вистината тука немала никаква улога.

${ }^{55}$ B. Gounaris, Social cleavages and national awaking in Ottoman Macedonia, East European Quaterly, XXIX, n. 4, Boulder, 1996, p. 416 


\section{Литература}

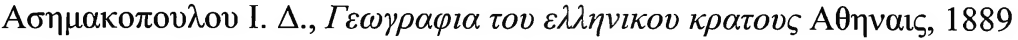

Betsas I., The objectives of the Greek foreign ministry for Greek education within the Ottoman state (1871-1912): The setting of objectives and the fundamental axes of activity in: Nikos Terzis (ed.), Education in the Balkans: From the Enlightenment to the Founding of the Nation states, Kyriakidis Brothers, Thessaloniki, 2000

Bonides K., Paskalas S., Balabani K., Nationalism and education: The propagation of the Great idea of Greek nationalism through education in the European territories of the Ottoman Empire in the late $19^{\text {th }}$ century in: Education in the Balkans: From the Enlightment to the founding of the nation states. Kyriakidis Brothers, Thessaloniki, 2000

Вилкинсон Х.Р., Картите и политиката. Преглед на Етнографската картографија на Македонија, Македонска книга, Скопје, 1992

Gounaris B., Social cleavages and national awaking in Ottoman Macedonia, East European Quaterly, XXIX, n. 4, Boulder, 1996

Гунарис В., Михаилидис Ј., Перото и мечот: преглед на историографијата за македонското прашање, во: Виктор Рудометов, Македонското прашање, Евро Балкан прес, Скопје, 2003

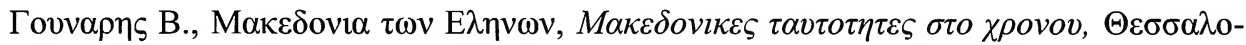
viкฑ, 2008

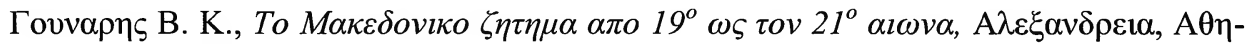
$v \alpha, 2010$

Данова Н., Националният въпрос в гръиките политически програми през ХIX век, Наука и изкуство, София, 1980

Demetriou K. N, Historians on Macedonian imperialism and Alexander the Great, Journal of Modern Greek Studies, v. 19, 2001

Јовановски Д., Грчката балканска политика и Македонија 1830-1881, Бато и Дивајн, Скопје, 2005

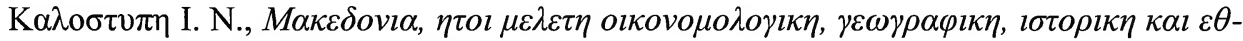

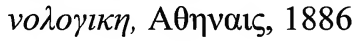

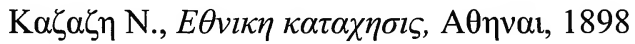

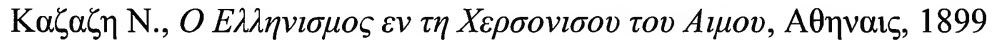

Kitromilides P., On the intellectual content of Greek nationalism: Paparrigopoulos, Byzantium and the Great idea in: D. Ricks and P. Magdalino (ed.) Byzantium and the Modern Greek identity, Ashgate Publishing, 1998

Kofos E., Dilemmas and orientations of Greek policy in Macedonia 1878-1896, Balkan Studies, 21, Institute for Balkan studies, Thessaloniki, 1980

Michalopoulos G., Greece and Macedonia: 1878-1910. Political parties, irredentism and the Foreign Ministry, $\mathrm{PhD}$ thesis, University of Oxford, 2013

Miller W., Greek life in town \& country, George Newnes ltd. London, 1905

Мојсов Л., Македонците во Егејска Македонија, Мисла, Скопје, 1989 


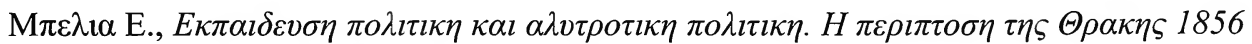

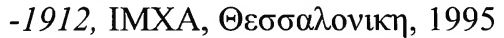

Nicolaides C., La Macedoine, la questioin macedonienne dans l'antique, au moyen-age et dans la politique actuelle, Johannes Ræde, Berlin, 1899

Notice explicative sur la Carte Ethnographique des pays Helleniques, Slaves, Albanais et Roumains, dessinee par M. Henri Kipert, Kerkes \& Hohmann. Berlin, 1878

Papadakis L., Teaching the nation. Greek nationalism and the Education in nineteenth century Macedonia, IBS, Thessaloniki, 2006

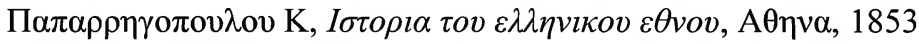

Peckham R. Sh., National Histories, national state. Nationalism and the politics of place in Greece, I.B. Tauris publishers, London - New York, 2001

Roudometof V., Invented traditions, symbolic boundaries and national identity in Southeastern Europe: Greece and Serbia in comparative historical perspective (18301880), East European Quarterly, XXXII, n.4, January, 1999

Rumbold H., Recollections of a diplomatist, Edward Arnold, London, 1902

Saripolos N., Pro Graecia, t.2, Athenes, 1853

Smith A., The cultural foundations of nations: hierarchy, covenant and republic. Blacwell Publishing, 2008

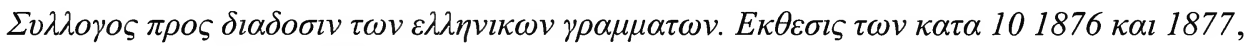

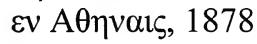

Tzanaki D., Women and Nationalism in the Making of Modern Greece, Palgrave Macmillan, 2009

Yosmaoğlu-Turner I., The priest's robe and the rebel's rifle: Communal conflict and construction of national identity in Ottoman Macedonia 1878-1908, PhD dissertation, Princeton University, November, 2005

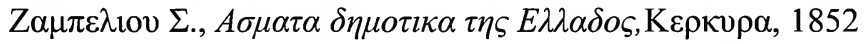

Zervas T. G., ,Resurrecting the Past, Constructing the Future: A Historical Investigation on the Formation of a Greek National Identity in Schools, 1834-1913“" (2010) Dissertations Paper 156, Loyola University Chicago 
Dalibor JOVANOVSKI

\section{HISTORY, EDUCATION, MAPS, STATISTICS, PROPAGANDA - GREECE AND OTTOMAN MACEDONIA IN $19^{\text {TH }}$ CENTURY}

\section{Summary}

After the well-known speech of Ioannis Kolettis in Greek Parliament in January 1844, Macedonia became one of the regions of Ottoman Empire toward which Greece directed its territorial ambitions. Thus, Macedonia became a significant place of the interest for Greek historians and other intellectuals. During the second half of $19^{\text {th }}$ century substantial changes took place in the Greek historiography. During the first two decades of Greek independent state, Ancient Macedonia and Byzantium were not considered as a part of the Greek past. However, after 1844, Ancient Macedonia and Byzantium became an important part of Greek heritage. The reason was very simple. Both of them were used for proving that Macedonia was a historical Greek land. So, this Ottoman region should become a part of the future expanded Greek state. On the other hand, the territory of the ancient Macedonian kingdom was used by the Greek intellectuals, in cartography, to prove that the northern part of Modern Macedonian region was not a historical Macedonia. However, ethnic composition of Macedonian population did not fit Greek interest. The Greek population in Ottoman Macedonia was a minor in comparison with the others. That was the main reason for creation of Athens society for the expansion of Greek education.

Keywords: MACEDONIA, GREECE, MAPS, STATISTIC, PROPAGANDA 